\title{
Prorodzinne świadczenia materialne a kształtowanie jakości życia rodzin w Irlandii i w Polsce w latach 2004-2013
}

\author{
Mariola Zalewska*, Natalia Sierżęa ${ }^{* *}$
}

$W$ artykule porównano jakość życia rodzin $w$ Irlandii $i w$ Polsce $w$ latach 2004-2013. Na jakość życia rodzin wptywa wiele czynników, $w$ tym dostępne $w$ danym kraju świadczenia materialne. Przedstawione analizy świadczeń rodzinnych $w$ Polsce $i w$ Irlandii ukazuja, iz finansowanie polityki rodzinnej w Irlandii jest bardziej korzystne dla rodzin - katalog oferowanych świadczeń jest szerszy, ich wysokość jest wyższa, a czas pobierania jest dtuższy niż w Polsce. Jeżeli chodzi o jakość życia, to porównano wskaźniki, których wartość opisuje zachowania pojedynczych ludzi, majace wptyw na szeroko rozumiane zycie rodzinne: poziom migracji, dzietność, liczby zawieranych i rozwiazywanych matżenstw. Wskaźniki te sa lepsze dla Irlandii niż dla Polski. Nie pozwala to jednak na jednoznaczne wskazanie zwiazku przyczynowo-skutkowego, wobec niemożności odwiktania wplywu wyższego poziomu PKB w Irlandii.

Słowa kluczowe: jakość życia rodzin, Polska, Irlandia, finansowanie polityki rodzinnej, analiza wskaźnikowa.

Nadesłany: 16.04.2016 | Zaakceptowany do druku: 28.10.2016

\section{Influence of family-oriented benefits on the quality of life of families in Ireland and in Poland in 2004-2013}

The article compares the quality of life of families in Ireland and in Poland in 2004-2013. The quality of life of families is affected by many factors, including available family-oriented benefits. These benefits are listed separately for Poland and Ireland to show that familyoriented financial policy in Ireland is more favourable than in Poland. Spectrum of offered services is in Ireland wider, amounts are higher, and durations are longer than in Poland. When it comes to the quality of life a comparison of the indicators was performed. These were selected value to address several aspects related to the family life: the level of migration, fertility, the number of marriages and divorces. These indicators look better for Ireland than for the Poland. However, this does not allow for clear identification of the causal relationship, because it is impossible to disentangle an impact of the level of GDP which is higher in Ireland than in Poland.

\footnotetext{
Dr Mariola Zalewska - Samodzielny Zakład Metod Matematycznych i Statystycznych Zarządzania, Wydział Zarządzania Uniwersytetu Warszawskiego.

Adres do korespondencji: Samodzielny Zakład Metod Matematycznych i Statystycznych Zarządzania, Wydział Zarządzania Uniwersytetu Warszawskiego, ul. Szturmowa 1/3, 02-687; e-mail: Zalewska@wz.uw.edu.pl.

** Mgr Natalia Sierżęga - e-mail: nataliasierzega@gmail.com.
} 
Keywords: quality of life of families, Poland, Ireland, funding for family-oriented policy, indicator analysis.

Submitted: 16.04.2016 | Accepted: 28.10.2016

JEL: H53, I31, J38, C43

\section{Wstęp}

Jakość życia interesuje nie tylko badaczy wielu dyscyplin, lecz także osoby kształtujące polityki rozwojowe i nimi zarządzające (Zalewska, 2015). Od lat prowadzi się interdyscyplinarne badania dotyczące pomiaru jakości życia (Constanza i in., 2007), wychodząc od nauk społecznych, ekonomii czy zarządzania (Stiglitz, Sen i Fitoussi, 2009). Niezależnie od analiz jakości życia dla populacji całych krajów coraz częściej prowadzi się badania na niższym poziomie agregacji danych. Bada się również jakość życia w podziale na wyróżnione obszary geograficzne, na przykład miasta (OFS, 2014), gminy (Reynard, 2016), lub poszczególne grupy ludzi: jakość życia osób po przebytej chorobie nowotworowej (Gotay i Muraoka, 1998), jakość życia ludzi młodych (Bradford, Rutherford i John, 2002). Jednocześnie podważana jest kompletność wskaźników używanych do monitorowania jakości życia takich jak najbardziej znany HDI (Human Development Index) (Stiglitz, Sen i Fitoussi, 2009). Jednym z czynników, który nie jest bezpośrednio brany pod uwagę przy określaniu jakości życia, jest poziom zadowolenia z życia rodzinnego. Odpowiadające w jakimś stopniu temu aspektowi statystyki występują jednak w grupach wskaźników dotyczących jakości życia.

Celem autorek jest $z$ jednej strony porównanie poziomu prorodzinnych świadczeń materialnych w Irlandii i w Polsce, a z drugiej - porównanie wybranych wskaźników dotyczących jakości życia rodzinnego w tych krajach w latach 2004-2013.

Do przeprowadzenia analizy porównawczej wybrano Irlandię, z uwagi na to, że jest to jeden z krajów o najwyższym współczynniku dzietności wśród krajów Unii Europejskiej oraz ze względu na zauważalny poziom migracji Polaków do Irlandii. Można przypuszczać, iż uznają, że będzie im się tam żyło lepiej. W badaniu użyto danych $\mathrm{z}$ baz danych Eurostatu oraz OECD.

\section{Pomiar jakości życia}

Zainteresowanie jakością życia jako dziedziną wiedzy rośnie. Dzieje się tak przynajmniej z dwóch powodów. Pierwszym $\mathrm{z}$ nich jest stałe dążenie do ujednolicenia istoty samego pojęcia, drugim - wzmożone poszukiwanie kryteriów oceny jakości życia.

W praktyce do pomiaru jakości życia rodzin można przyjąć przynajmniej trzy podejścia:

1) podejście ekonomiczne - wykorzystuje ono mierniki, w skład których wchodzą: indeksy, wskaźniki, stopy itp., utworzone w ramach różnorodnych teorii ekonomicznych. Wśród nich jako najważniejszą wymienia się teorię ekonomii dobrobytu, z której wynikają mierniki dobrobytu. (Nussbaum i Sen, 1993);

2) podejście statystyczne - W tym podejściu, podobnie jak w ekonomicznym, tworzy sie pojedyncze mierniki, zbiory mierników lub konstruuje syntetyczne, które nazywa sie syntetycznymi wskaźnikami rozwoju społeczno-gospodarczego bądź gospodarczego. Charakteryzuja się one wysoką przydatnością praktyczną do podejmowania decyzji. Podejście statystyczne do oceny czy pomiaru jakości życia nie jest budowane na konkretnym modelu teoretycznym, co może być uważane za mankament, jednakże jest to podejście najbardziej popularne i najszerzej stosowane wśród badaczy (Hagerty $\mathrm{i}$ in., 2001);

3) podejście psychologiczne - jest odmienne od podejść przedstawionych wcześniej. Polega ono na badaniu wybranych grup społeczeństwa za pomocą badania ankietowego, którego głównym celem jest określenie subiektywnego postrzegania przez ludzi zjawiska jakości życia jako całości, bądź jego poszczególnych (odrębnych) aspektów (Diener i Suh, 1997).

W tym artykule porównujemy oferowane dla rodzin świadczenia materialne w Irlandii i w Polsce, w ramach prowadzonej przez 
kraje polityki społecznej w szczególności polityki rodzinnej. Do analizy jakości życia rodzin stosujemy podejście statystyczne. Rozpatrujemy wybrane wskaźniki po kolei, bez uciekania się do konstruowania wskaźnika zagregowanego, ponieważ uważamy, że byłoby to podejście nadmiarowe przy porównywaniu dwóch krajów. Dla każdego uwzględnionego w opracowaniu wskaźnika jest oczywiste, czy jego wyższe, czy niższe wartości odpowiadają wyższej jakości życia. Jest to jednak dodatkowo przez nas omawiane. Wybrane wskaźniki uważamy za reprezentację ważnych aspektów jakości życia rodzinnego. Nie uważamy jednak tej reprezentacji za wyczerpujacca. Wobec braku jednoznacznej wykładni terminu „jakość życia rodzinnego" odwołujemy się do jego intuicyjnego rozumienia $\mathrm{z}$ jednej strony oraz właśnie do wybranej grupy wskaźników, jako jego reprezentacji, z drugiej strony.

\section{Polityka społeczna i polityka rodzinna - ramy zagadnienia}

Polityka społeczna (ang. social policy) to działalność państwa oraz organizacji społecznych w obrębie kształtowania warunków życia oraz pracy, której głównym celem jest zaspokojenie społecznych oraz indywidualnych potrzeb człowieka. Katalog celów polityki społecznej wymienia je (Rysz-Kowalczyk, 2002, s. 118), tu wskazujemy jedynie te dziedziny działania, które dotyczą jakości życia rodzin, czyli: system zabezpieczenia społecznego, sprawy mieszkaniowe oraz edukację, walkę z bezrobociem, ochronę i higienę pracy, politykę zwalczania dyskryminacji i patologii społecznych, a także przeciwdziałanie wykluczeniu społecznemu.

W literaturze można znaleźć przegląd modeli polityki społecznej. Większość $\mathrm{z}$ nich bazuje na relacjach, jakie zachodzą między rynkiem, państwem i rodziną (Zalewska, 2013).

Przechodząc do rozważań nad polityką rodzinną, warto przytoczyć, jak definiowana jest rodzina. Dla socjologów rodzina to podstawowa mikrostruktura społeczna, która: historycznie jest najstarszą forma życia społecznego, o charakterze najbardziej powszechnym, jest podstawą istnienia społeczeństwa, na co wskazują wypełniane zadania i funkcje (Mazur, 2013, s. 23). Ekonomiści natomiast największy nacisk kładą na istnienie wspólnoty majątkowej i dochodowej, która ma być swoistym wyrazem więzi rodzinnej między partnerami. W tym celu posługują się najczęściej pojecciem gospodarstwa domowego, które ma w pewien sposób obrazować wspólnotę dochodów i wydatków (Święch, 2013, s. 25). Należy podkreślić, że rodzina i gospodarstwo domowe nie są pojęciami tożsamymi.

Jeszcze inne podejście do tego zagadnienia przedstawiaja prawnicy czy pedagodzy (Orczyk, 2012, s. 190). Jeśli chodzi o usankcjonowanie prawne, w polskim prawie rodzinnym pojęcie rodziny nie zostało zdefiniowane. W kodeksie rodzinnym i opiekuńczym można znaleźć jedynie przesłanki, które pomogłyby w określeniu, czym jest rodzina. Zgodnie $\mathrm{z}$ art. 27 k.r.o. ${ }^{1}$ na małżonkach (kobiecie i mężczyźnie) spoczywa obowiązek zaspokajania potrzeb rodziny, którą założyli, wstępując ze sobą w związek małżeński². W świetle prawa rodzinę tworzą rodzice i dzieci, nawet w przypadku, gdy między rodzicami nie zachodzi więź prawna. K.r.o. wskazuje także na więzi rodzinne zachodzace między ludźmi (chodzi tu o pokrewieństwo i powinowactwo), które warunkują zarówno prawa, jak i obowiązki adresatów norm prawnych (np. obowiązku alimentacyjnego w określonych w ustawie przypadkach). W art. 6 Ustawy o pomocy społecznej można znaleźć inna definicje rodziny. W rozumieniu tego artykułu rodzinę tworzą osoby spokrewnione lub niespokrewnione, które pozostaja ze sobą w faktycznym związku, a dodatkowo zamieszkują w jednym domu i wspólnie gospodarują.

Termin „polityka rodzinna” obejmuje takie działania władz państwowych na rzecz rodziców i ich dzieci, które mają na celu poprawianie sytuacji życiowej i materialnej rodzin posiadających dzieci, a także rodzin zastępczych zgodnie z Konstytucja Rzeczpospolitej Polskiej ${ }^{3}$. Kurzynowski (1991, s. 96) opisuje, że polityka rodzinna to wszelkie normy prawne oraz działania (materialne i niematerialne) państwa, mające na celu stworzenie rodzinie takich warunków, by swobodnie mogła powstać, a następnie prawidłowo się rozwijać.

W raporcie Jakiej polityki rodzinnej potrzebuje Polska? (Ordo Iuris, 2015) przedstawiono wyniki badań polityki rodzinnej siedmiu państw europejskich, które po 1990 r. osiagneły wzrost współczynnika dzietności. Doświadczenia pokazują, że 
mimo zróżnicowań można wskazać cechy wspólne polityki prorodzinnej:

„różnorodne formy wsparcia materialnego mają charakter prosty i powszechny; przynajmniej cześć wsparcia jest udzielana w postaci bezpośrednich świadczeń przekazywanych rodzicom; wysokość wsparcia przekazywanego bezpośrednio kształtuje sie na poziomie zbliżonym do sumy podatków pośrednich, które rodzice płacą w związku z nakładami na wychowanie dziecka”.

\section{Powszechne świadczenia materialne dla rodzin w Irlandii i w Polsce ${ }^{4}$}

Zarówno, Irlandia, jak i Polska oferują rozbudowany system pomocy rodzinom, dlatego nie wszystkie formy pomocy zostaną wymienione i omówione w tym artykule. Wymieniamy jedynie najważniejsze świadczenia materialne, a omawiamy powszechne świadczenia materialne.

Uznaje się, że Irlandia należy do liberalnego modelu polityki społecznej jednocześnie jest to kraj o jednym $\mathrm{z}$ najwyższych współczynniku dzietności w całe Unii Europejskiej. Irlandia zapewnia dwa powszechne świadczenia materialne - zasiłek na dziecko Child Benefit, oraz zasiłek macierzyński - Maternity Benefit. Ponadto oferuje także inne, których otrzymanie jest zależne od sytuacji materialnej rodziców lub opiekunów: zasiłek adopcyjny, dodatek rodzinny, zasiłek dla samotnego rodzica.

Najbardziej znaną i najbardziej rozpowszechnioną formą pomocy dla rodzin z dziećmi jest zasiłek na dziecko. Jest on wypłacany rodzicom, bądź opiekunom dzieci poniżej 16. roku życia lub do 18 . roku życia - w przypadku, gdy dziecko uczy sie w tzw. trybie dziennym, bierze udział w szkoleniach Youthreach, zostało zarejestrowane w FAS $^{5}$ lub gdy jest niepełnosprawne. Rodzicom dzieci, które ukończyły 16. rok życia i spełniaja kryterium nauki w pełnym wymiarze godzin, zasiłek przysługuje jedynie do czerwca. Kolejne świadczenia zostają przyznane dopiero w chwili, gdy dziecko ponownie zaczyna uczyć się w trybie dziennym. Wysokość tego zasiłku zależy jedynie od liczby posiadanych dzieci. Miesięczna stawka na dziecko poniżej 18. roku życia wynosiła w roku 2015 dla jednego dziecka 135 euro, dla kolejnych dzieci wielokrotność tej kwoty. Zasiłek dla bliźniąt wynosi $150 \%$ miesięcznej stawki dla każdego dziecka, zaś dla trojaczków i większej liczby dzieci wynosi $200 \%$ miesięcznej stawki, pod warunkiem, że przynajmniej trójka dzieci kwalifikuje się do tego zasiłku. O zasiłek można ubiegać sie od momentu narodzin dziecka, od miesiąca, w którym dziecko stało sie członkiem rodziny, badź od miesiąca, w którym rodzina przybyła do Irlandii (obywatele krajów UE i EOG nie muszą być na stałe zameldowani, by otrzymywać ten zasiłek, moga pobierać go Polacy, którzy wyemigrowali do Irlandii w poszukiwaniu pracy wraz ze swoimi rodzinami $)^{6}$.

Drugie powszechne świadczenie dla rodzin to zasiłek macierzyński. Wypłacany jest tygodniowo kobietom przebywającym na urlopie macierzyńskim po narodzinach dziecka. Warunkiem otrzymania tego świadczenia jest odpowiedni okres oplacania składek na ubezpieczenia społeczne (minimum 39 tygodni w ciagu 12 miesięcy przed przejściem na urlop lub 52 tyg. w przypadku kobiet samozatrudnionych), a także pozostawanie w stosunku pracy do momentu przejścia na urlop macierzyński (można rozpocząć go najwcześniej 16 tyg., a najpóźniej 2 tygodnie przed planowaną datą porodu). Aby uzyskać zasiłek macierzyński, przyszła matka powinna ubiegać się o niego najpóźniej na 6 tyg. przed pierwszym dniem urlopu macierzyńskiego, zaś kobieta prowadząca własna działalność gospodarczą najpóźniej 12 tyg. przed tym dniem. Od 2007 roku zasiłek macierzyński wypłacany jest co tydzień przez okres 26 tygodni, a jego wysokość uzależniona jest od wysokości zarobków. Od 2014 r. minimalna tygodniowa stawka tego świadczenia wynosi 230 euro, zaś maksymalna 262 euro (należy tu wspomnieć, iż od 1 lipca 2013 r. zasiłek macierzyński podlega opodatkowaniu, nie podlega natomiast opłacie socjalnej oraz PRSI). Istnieje jednak odstępstwo od tej reguły - jeżeli na utrzymaniu kobiety pozostają inne osoby (np. mąż i dzieci), to wysokość tego świadczenia porównywana jest ze stawką zasiłku chorobowego, która otrzymałaby ona $z$ tytułu nieobecności z zakładzie pracy z powodu choroby i wypłacana jest jej ta kwota, która jest wyższa. W takim przypadku kwota świadczenia macierzyńskiego może być wyższa od najwyższej stawki, czyli od wcześniej wspomnianych 262 euro $^{7}$. Natomiast osoby, które otrzymują jedno z następujących świadczeń socjalnych: dodatek dla rodzin niepełnych, rentę „wdowią”, dodatek dla kobiet, które 
opuścili mężowie, zapomogę dla żon więźniów czy odprawę pośmiertną w formie renty lub alimentów, otrzymują jedynie połowę kwoty zasiłku macierzyńskiego ${ }^{8}$.

Polska zapewniała przez długi czas tylko jedno powszechne świadczenia materialne - zasiłek macierzyński (lub jego równoważnik - świadczenia rodzicielskie). W lutym 2016 r. weszło w życie Rozporządzenie Ministra Rodziny, Pracy i Polityki Społecznej w sprawie sposobu i trybu postępowania w sprawach o świadczenie wychowawcze, tzw. Ustawa 500 plus $^{9}$. Zgodnie z Ustawa to świadczenie moga otrzymać rodzice, opiekunowie prawni lub faktyczni dziecka na drugie i kolejne dziecko, do ukończenia 18. roku życia dziecka. Na pierwsze dziecko wsparcie otrzymaja jedynie ci rodzice, których dochód na osobę w rodzinie nie przekracza 800 zł netto albo 1200 zł netto na osobę, w której wychowywane jest dziecko niepełnosprawne.

Ponadto wśród świadczeń rodzinnych można wymienić inne (nie są one powszechne, ich przyznanie warunkuje sytuacja materialna rodziny): zasiłek rodzinny wraz z dodatkami, jednorazowa zapomoga $z$ tytułu urodzenia dziecka świadczenie opiekuńcze, a także zasiłek dla opiekuna.

Powszechnym świadczeniem pieniężnym dla kobiet po urodzeniu dziecka jest zasiłek macierzyński. Przysługuje on osobie ubezpieczonej (a więc pozostającej w zatrudnieniu), która w czasie urlopu wychowawczego badź w okresie ubezpieczenia chorobowego: urodziła dziecko, przyjęła na wychowanie dziecko w wieku do 7. roku życia i z tego tytułu wystąpiła o jego przysposobienie do sadu opiekuńczego lub stworzyła dla dziecka do 7. roku życia rodzinę zastępczą (z wyjątkiem rodziny zastępczej zawodowej). Zasiłek macierzyński wypłaca się przez okres odpowiadający okresowi urlopu macierzyńskiego trwającego od 20 do 37 tygodni w zależności od liczby nowo narodzonych dzieci. O zasiłek taki moga ubiegać sie również ubezpieczeni ojcowie dziecka bądź inni pracujący członkowie rodziny, ale tylko w określonym przepisami przypadku, a mianowicie gdy matka dziecka porzuci je lub umrze, a osoby te będe zmuszone do zrezygnowania z pracy, by móc w pełni opiekować się dzieckiem. Ojciec dziecka może skorzystać z zasiłku macierzyńskiego, jeśli matka dziecka wykorzysta minimum 14 tygodni z przysługującego jej urlopu macierzyńskiego. Dodatkowo, w przypadku jeśli jest ubezpieczony i fak- tycznie sprawuje opiekę nad dzieckiem, to przysługuje mu prawo do pobierania zasiłku macierzyńskiego przez okres odpowiadający okresowi urlopu ojcowskiego, czyli przez okres 2 tygodni, jednak nie można sie ubiegać o niego w przypadku ukończenia przez dziecko 1. roku życia. Jeśli chodzi o wysokość zasiłku macierzyńskiego, jest ona różna w zależności od urlopu, na jakim przebywa matka dziecka. W przypadku, gdy okres wypłacania tego zasiłku odpowiada okresowi urlopu macierzyńskiego, urlopu na warunkach urlopu macierzyńskiego, dodatkowego urlopu macierzyńskiego lub dodatkowego urlopu przyznawanego na warunkach urlopu macierzyńskiego, to jego wysokość wynosi $100 \%$ podstawy wymiaru, natomiast za okres odpowiadający okresowi urlopu rodzicielskiego jego wysokość kształtuje się na poziomie $60 \%$ podstawy wymiaru tego zasiłku, szczegóły (MPIPS, www.mpips.gov.pl).

Polityka prorodzinna w Polsce cały czas powoli się zmienia, próbując dostosować sie do stale rozwijajacego sie społeczeństwa. Od początku 2016 r. istnieje nowe powszechne świadczenie rodzicielskie, którego adresatami są studenci, rolnicy, osoby pracujące na umowie o dzieło lub umowie zlecenia, a także osoby bezrobotne. Jak widać, sa to osoby, którym do tej pory nie przysługiwały urlopy macierzyńskie i rodzicielskie. Swiadczenie takie wynosić będzie 1000 zł miesięcznie i będzie wypłacane przez pierwszy rok życia dziecka.

W przypadku, gdy kobieta podczas jednego porodu urodzi więcej niż jedno dziecko, okres otrzymywania takiego świadczenia będzie się wydłużać w zależności od liczby urodzonych dzieci i maksymalnie wyniesie 71 tyg. od dnia narodzin dzieci. Jest to świadczenie powszechne równoważne z zasiłkiem macierzyńskim, bez żadnego kryterium dochodowego, przeznaczone dla innej grupy odbiorców.

Istotną różnicą między Irlandią a Polską jest powszechność i wysokość wypłacanych świadczeń. W Polsce większość świadczeń jest adresowana wyłącznie do rodzin w bardzo trudnej sytuacji materialnej. Do rodzin o wyższych dochodach jest przeznaczony wyłącznie zasiłek macierzyński (albo świadczenie rodzicielskie). Ponadto występuje różnica w wysokości świadczeń; kwoty są znacząco niższe, a ich otrzymanie wymaga spełnienia bardziej restrykcyjnych warunków. Jak pokazano w tabeli 1, łącznie na świadczenia rodzinne przeznacza się 
Tabela 1.Wydatki Irlandii, Polski, krajów OECD, na świadczenia rodzinne w gotówce, usługach, ulgach podatkowych wyrażone w procencie PKB w 2011 r.

\begin{tabular}{|l|r|r|r|r|r|r|r|r|c|c|}
\hline & \multicolumn{10}{|c|}{ Rok } \\
\cline { 2 - 11 } & $\mathbf{2 0 0 4}$ & $\mathbf{2 0 0 5}$ & $\mathbf{2 0 0 6}$ & $\mathbf{2 0 0 7}$ & $\mathbf{2 0 0 8}$ & $\mathbf{2 0 0 9}$ & $\mathbf{2 0 1 0}$ & $\mathbf{2 0 1 1}$ & $\mathbf{2 0 1 2}$ & $\mathbf{2 0 1 3}$ \\
\hline Populacja Irlandii w mln. & 4,03 & 4,11 & 4,21 & 4,34 & 4,46 & 4,52 & 4,55 & 4,57 & 4,58 & 4,59 \\
\hline $\begin{array}{l}\text { Irlandia - \% przyrost popu- } \\
\text { lacji w stosunku do roku } \\
\text { poprzedniego }\end{array}$ & - & 2,06 & 2,35 & 3,14 & 2,71 & 1,43 & 0,62 & 0,47 & 0,26 & 0,18 \\
\hline Populacja Polski w mln. & 38,19 & 38,17 & 38,16 & 38,13 & 38,12 & 38,14 & 38,02 & 38,06 & 38,06 & 38,06 \\
\hline $\begin{array}{l}\text { Polska - \% przyrost popu- } \\
\text { lacji w stosunku do roku } \\
\text { poprzedniego }\end{array}$ & - & $-0,04$ & $-0,04$ & $-0,08$ & $-0,03$ & 0,05 & $-0,30$ & 0,10 & 0,0028 & $-0,0033$ \\
\hline
\end{tabular}

Źródło: opracowanie własne na podstawie: http://www.oecd.org/social/family/database.htm (27.04.2015).

w Irlandii 4\%, w krajach OECD 2,55\%, w Polsce $1,75 \%$ PKB tych krajów.

\section{Analiza jakości życia rodzin w Irlandii i w Polsce}

W tej części zostanie poddana analizie jakość życia rodzin w Irlandii i w Polsce w okresie od 2004 do 2013 r., a więc od momentu wejścia Polski do Unii Europejskiej. Autorki wybrały następujące mierniki:

1. Całkowita populacja.

2. Migracje.

3. Warunki materialne: PKB w przeliczeniu na mieszkańca w standardzie siły nabywczej.

4. Współczynnik dzietności.

5. Liczba zawieranych małżeństw oraz przeprowadzanych rozwodów.

Wszystkie dane przyjęte do niniejszego opracowania pochodzą z publicznych baz danych statystycznych udostępnianych przez organizacje takie jak Eurostat czy GUS, a także z baz danych OECD.

\subsection{Całkowita wielkość populacji}

Autorki stoją na stanowisku, że dynamika całkowitej wielkość populacji ma kardynalne znaczenie. Świadczy o tym, czy ludzie chca mieszkać i rozwijać się na badanym obszarze (kontynencie, kraju, gminie), czy - przeciwnie - wybieraja inne miejsca do życia. Wskaźnikiem jest liczba rezydentów (mieszkańców) danego kraju w dniu 1 stycznia danego roku. Liczbę mieszkańców Irlandii i Polski przedstawiono w tabeli 2.

Najwyższy poziom wskaźnika odnotowano w Polsce w 2004 roku - populacja wyniosła wówczas 38190608 osób. Od tamtego czasu, aż do 2010 r., liczba mieszkańców Polski malała (co m.in. było spowodowane emigracją), jednak wciąż pozostawała

Tabela 2. Całkowita populacja w Irlandii i w Polsce w latach 2004-2013

\begin{tabular}{|l|c|c|c|c|c|c|c|c|c|c|}
\hline & \multicolumn{10}{|c|}{ Rok } \\
\cline { 2 - 11 } & $\mathbf{2 0 0 4}$ & $\mathbf{2 0 0 5}$ & $\mathbf{2 0 0 6}$ & $\mathbf{2 0 0 7}$ & $\mathbf{2 0 0 8}$ & $\mathbf{2 0 0 9}$ & $\mathbf{2 0 1 0}$ & $\mathbf{2 0 1 1}$ & $\mathbf{2 0 1 2}$ & $\mathbf{2 0 1 3}$ \\
\hline Irlandia & 4,03 & 4,11 & 4,21 & 4,34 & 4,46 & 4,52 & 4,55 & 4,57 & 4,58 & 4,59 \\
\hline $\begin{array}{l}\text { Zmiana w stosunku do roku } \\
\text { poprzedniego (w \%) }\end{array}$ & - & 2,06 & 2,35 & 3,14 & 2,71 & 1,43 & 0,62 & 0,47 & 0,26 & 0,18 \\
\hline Polska & 38,19 & 38,17 & 38,16 & 38,13 & 38,12 & 38,14 & 38,02 & 38,06 & 38,06 & 38,06 \\
\hline $\begin{array}{l}\text { Zmiana w stosunku do roku } \\
\text { poprzedniego (w \%) }\end{array}$ & - & $-0,04$ & $-0,04$ & $-0,08$ & $-0,03$ & 0,05 & $-0,30$ & 0,10 & 0,0028 & $-0,0033$ \\
\hline
\end{tabular}

Źródło: opracowanie własne na podstawie: http://ec.europa.eu/eurostat/tgm/refreshTableAction.do?ta$b=$ table\&plugin $=1 \&$ pcode $=$ tps00001\&language $=$ en $(19.05 .2015)$. 
Rysunek 1. Roczny przyrost populacji w Irlandii i w Polsce w latach 2004-2013 [\%]

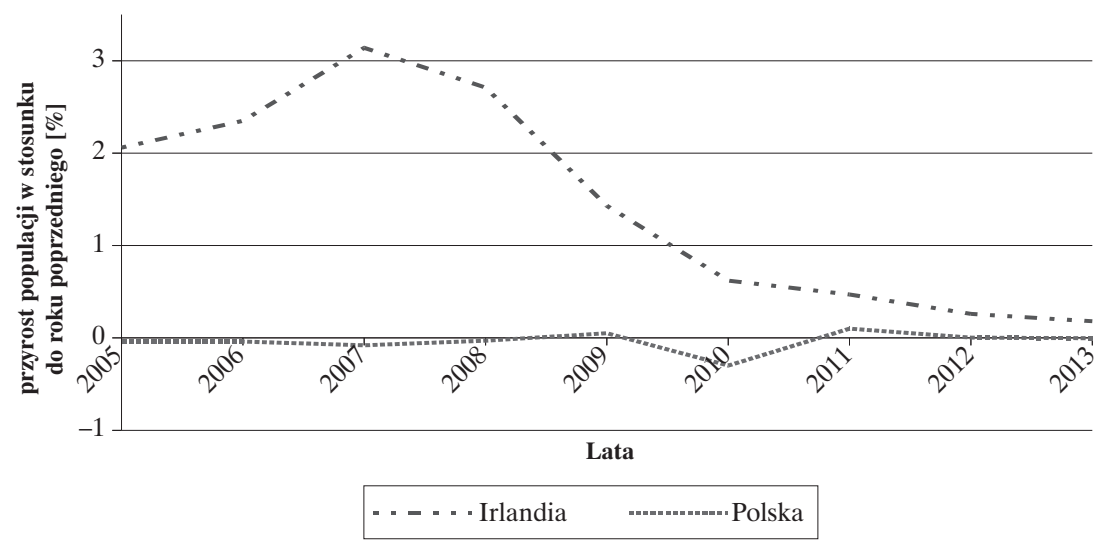

Źródło: opracowanie własne na podstawie: http://ec.europa.eu/eurostat/tgm/refreshTableAction.do? tab $=$ table \&plugin $=1 \&$ pcode $=$ tps00001\&language $=$ en $($ dostęp: 19.05.2015).

powyżej 38 mln osób. Najniższą wartość 38022869 osób odnotowano właśnie w 2010 roku. Trend spadkowy został przełamany w latach 2011-2012, w których odnotowano niewielki przyrost liczby ludności Polski (odpowiednio o $0,10 \%$ i $0,0028 \%$ w porównaniu do roku poprzedniego). W 2013 r. znów zanotowano spadek tego wskaźnika.

Jeżeli chodzi o Irlandie, to populacja tego kraju w badanym okresie rosła. Najniższą wartość analizowanego wskaźnika odnotowano w 2004 r., kiedy to populacja Irlandii wyniosła 4028851 osób, najwyższą zaś w 2013 r. - liczba ludności tego kraju wyniosła 4591087 osób. Na przestrzeni 9 lat liczba ludności Irlandii wzrosła zatem łącznie o ponad pół miliona osób, czyli o około $13,96 \%$.

\subsection{Migracje}

W związku z wielkościa populacji i jej zmianami warto przeanalizować wielkość migracji zewnętrznych, czyli przemieszczeń ludności między terytoriami (poza granice państwa) związanej ze względnie trwałą zmianą miejsca zamieszkania (tab. 3).

Jeśli chodzi o Irlandię, z danych zawartych w tabeli 3 wynika, że do roku 2006

Tabela 3. Migracje ludności Irlandii i Polski w latach 2004-2013 (w tysiącach osób)

\begin{tabular}{|c|c|c|c|c|c|c|c|c|c|c|c|c|}
\hline \multicolumn{13}{|c|}{ Liczba migrantów w tysiącach osób, w Irlandii i w Polsce w latach 2004-2013 } \\
\hline \multirow{2}{*}{ Kraj } & \multirow{2}{*}{ Migracja } & \multicolumn{10}{|c|}{ Rok } & \multirow{2}{*}{$\begin{array}{l}\text { Skumulowana } \\
\text { migracja } \\
\text { w latach } \\
\text { 2004-2013 }\end{array}$} \\
\hline & & 2004 & 2005 & 2006 & 2007 & 2008 & 2009 & 2010 & 2011 & 2012 & 2013 & \\
\hline \multirow{3}{*}{ Irlandia } & imigracja & 78,1 & 102,0 & 139,4 & 122,4 & 82,6 & 50,6 & 52,3 & 53,2 & 54,4 & 59,3 & 794,4 \\
\hline & emigracja & 28,7 & 34,4 & 44,4 & 48,0 & 65,9 & 69,7 & 78,1 & 87,1 & 89,4 & 83,8 & 629,5 \\
\hline & \begin{tabular}{|l|} 
saldo \\
migracji
\end{tabular} & 49,4 & 67,7 & 95,0 & 74,4 & 16,7 & $-19,1$ & $-25,8$ & $-33,8$ & $-35,0$ & $-24,5$ & 165,0 \\
\hline \multirow{3}{*}{ Polska } & imigracja & 9,5 & 9,4 & 10,8 & 15,0 & 4,8 & 189,2 & 155,1 & 157,1 & 217,5 & 220,3 & 988,7 \\
\hline & emigracja & 18,9 & 22,2 & 46,9 & 35,5 & 74,3 & 229,3 & 218,1 & 265,8 & 275,6 & 276,4 & 1463,2 \\
\hline & \begin{tabular}{|l|} 
saldo \\
migracji
\end{tabular} & $-9,4$ & $-12,9$ & $-36,1$ & $-20,5$ & $-69,6$ & $-40,2$ & $-63,0$ & $-108,7$ & $-58,1$ & $|-56,1|$ & $-474,5$ \\
\hline
\end{tabular}

Źródło: opracowanie własne na podstawie: http://ec.europa.eu/eurostat/tgm/table.do?tab=table\&init=1\& language $=$ en $\&$ pcode $=$ tps00177\&plugin $=1$ (emigracja) oraz http://ec.europa.eu/eurostat/tgm/table. do?tab=table\&init $=1 \&$ language $=$ en\&pcode $=$ tps00176\&plugin $=1$ (imigracja) 
Rysunek 2. Procentowy udział imigrujących do Irlandii i Polski w populacji tych krajów w latach 2004-2013 (w \%)

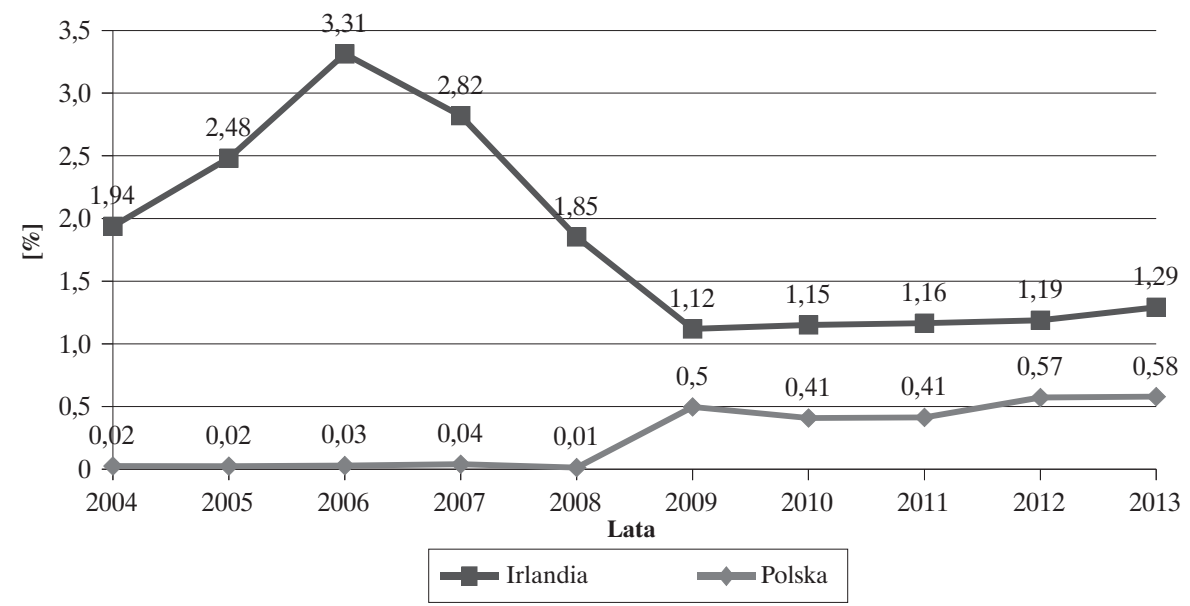

Źródło: opracowanie własne na podstawie danych z tabel 2 i 3.

liczba imigrantów dynamicznie rosła, następnie przez trzy lata gwałtownie spadała, by od roku 2009 ustabilizować się (z lekkim, w porównaniu do wcześniejszych gwałtownych zmian, trendem wzrostowym; zob. rys. 2). Liczba emigrantów Irlandii rosła w latach 2004-2012 (tab. 3 oraz rys. 3). Od 2009 roku notuje sie tam ujemne saldo migracji.
W Polsce liczby, tak emigrantów, jak imigrantów, gwałtownie wzrosły w roku 2009. Wcześniej utrzymywały się na niskim poziomie, a później ustabilizowały się na dość wysokim poziomie około 200 tysięcy rocznie, przy czym saldo migracji było stale ujemne i kształtowało się na poziomie około 20 tysięcy rocznie do roku 2007 oraz około 60 tysięcy rocznie od roku 2008.

Rysunek 3. Procentowy udział emigrujących z Irlandii i Polski w populacji tych krajów w latach 2004-2013 (w \%)

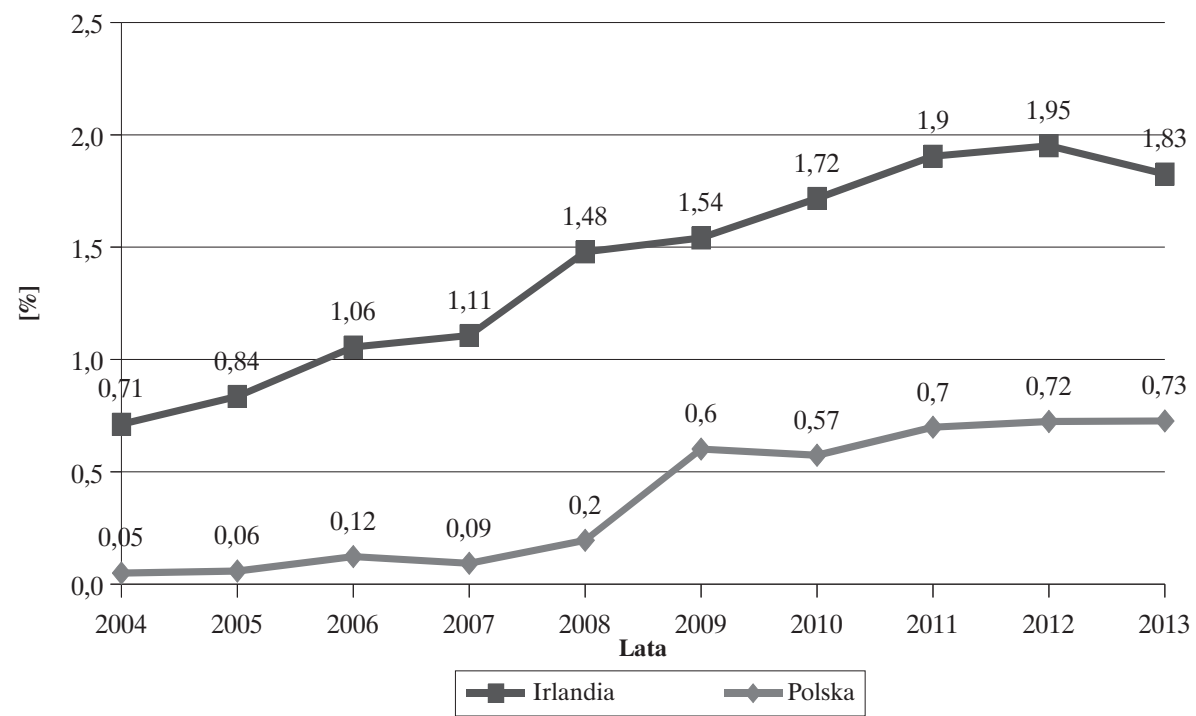

Źródło: opracowanie własne na podstawie danych z tabel 2 i 3. 
Obserwowany gwałtowny wzrost jest jednak najprawdopodobniej artefaktem wywołanym zmianą kryteriów uznawania (przez m.in. Polskę) kogoś za imigranta lub emigranta.

W całym badanym okresie odsetek ludności emigrującej z Polski był znacznie mniejszy niż w przypadku Irlandii, co wyraźnie widać na rysunku 3. Odsetek ludności imigrującej jest również na dużo niższym poziomie (rys. 2). W dodatku dynamika kształtowania się tego odsetka dla Irlandii jest dość zaskakująca. Można ją jednak, przynajmniej jakościowo, objaśnić za pomocą dynamiki PKB, która zostanie omówiona w następnym podrozdziale.

\subsection{PKB na mieszkańca $w$ standardzie sily nabywczej}

By móc porównać stope życiową ludności w różnych krajach, a tym samym lepiej ocenić sytuację materialną, wzięto pod uwagę produkt krajowy brutto przypadający na jednego mieszkańca, czyli tzw. PKB per capita. Dodatkowo, powinno uwzględnić się siłę nabywczą, czyli ile przeciętny mieszkaniec danego kraju może kupić dóbr i usług za przypadającą na niego część PKB, a więc zastosować produkt krajowy brutto per capita w parytecie (standardzie) siły nabywczej. Trzeba jednak podkreślić, że miernik ten nie w pełni oddaje sytuację materialną społeczeństwa, ponieważ nie uwzględnia np. pracy na czarno czy efektów pracy wykonywanej na własne potrzeby (Adamowicz, 2008, s. 32). Nie pretenduje również do ujmowania wpływu takich czynników jak ilość czasu wolnego.

W tabeli 4 umieszczono wartości stosunku PKB per capita $\mathrm{w}$ standardzie sily nabywczej (ang. purchasing power standards - PPS ${ }^{10}$ ) do średniej dla wszystkich 28 kra- jów Unii Europejskiej. Z analizy danych zawartych w tej tabeli wynika, iż w Irlandii w latach 2004-2007 wartość PKB w przeliczeniu na mieszkańca wyrażona w PPS była prawie trzykrotnie wyższa niż w Polsce. W rozpatrywanym okresie największa jej wartość przypadła w Irlandii na 2007 rok, ale w kolejnym roku gwałtownie spadła o 15 punktów procentowych, a następnie nastąpił okres stagnacji na poziomie około $130 \%$ średniej UE28. Jeśli zaś chodzi o Polskę, to z roku na rok wartość PKB per capita w standardzie siły nabywczej rośnie. Choć pozostaje poniżej średniej dla Unii Europejskiej, to „małymi krokami” zbliża się do niej. Najmniejszą wartość analizowanego wskaźnika odnotowano w Polsce w 2004 r., kiedy to wyniosła $49 \%$ średniej UE28. W kolejnych dwóch latach utrzymywała się ona na stałym poziomie $50 \%$, a od 2007 r. stopniowo rosła, by osiągnąć najwyższą wartość w 2013 r., kiedy to wyniosła 67\%. Przyrost absolutny tego wskaźnika w całym badanym okresie wyniósł zatem 18 punktów procentowych. Od 2009 roku wskaźnik dla Polski jest już tylko o około czynnik dwa (a nie trzy) niższy niż dla Irlandii.

Kształtowanie się PKB dla Irlandii jest jednym z głównych czynników objaśniających dynamikę poziomu imigracji do tego kraju. Dynamika wzrostu PKB załamywała się już w 2006 roku, co spowodowało skurczenie się rynku pracy w kolejnych dwóch latach, skutkujące gwałtownym obniżeniem się liczby imigrantów. Natomiast stabilizacja PKB po roku 2009 spowodowała najprawdopodobniej ustalenie się poziomu imigracji.

\subsection{Dzietność}

Jednym z ciekawszych indykatorów zmian jakości życia społeczeństwa jest

Tabela 4. Stosunek PKB per capita w standardzie sity nabywczej (PPS) w Irlandii i w Polsce w latach 2004-2013 do średniej dla 28 krajów UE (wartości w tabeli podane są w procentach)

\begin{tabular}{|l|c|c|c|c|c|c|c|c|c|c|}
\hline \multirow{2}{*}{ Kraj } & \multicolumn{10}{|c|}{ Rok } \\
\cline { 2 - 12 } & $\mathbf{2 0 0 4}$ & $\mathbf{2 0 0 5}$ & $\mathbf{2 0 0 6}$ & $\mathbf{2 0 0 7}$ & $\mathbf{2 0 0 8}$ & $\mathbf{2 0 0 9}$ & $\mathbf{2 0 1 0}$ & $\mathbf{2 0 1 1}$ & $\mathbf{2 0 1 2}$ & $\mathbf{2 0 1 3}$ \\
\hline UE28 & 100 & 100 & 100 & 100 & 100 & 100 & 100 & 100 & 100 & 100 \\
\hline Irlandia & 143 & 145 & 146 & 147 & 132 & 128 & 129 & 130 & 130 & 130 \\
\hline Polska & 49 & 50 & 50 & 53 & 55 & 59 & 62 & 64 & 66 & 67 \\
\hline
\end{tabular}

Źródło: opracowanie własne na podstawie: $h$ ttp://ec.europa.eu/eurostat/tgm/table.do?tab=table\&ini$t=1$ \&language $=$ en $\&$ code $=$ tec00114\&plugin $=1$ (05.07.2015). 
zmiana poziomu dzietności, po odwikłaniu zmian związanych ze strukturą demograficzną. Sam poziom jest uwarunkowany kulturowo i demograficznie. Porównywanie różnych społeczeństw jest trudne. W przypadku Polski i Irlandii różnica jest jednak kolosalna. O ile Irlandia wykazuje współczynnik na poziomie zastępowania pokoleń, o tyle Polska jest społeczeństwem wymierającym. Ciągniemy europejską średnią w dół. Widoczne w tabeli 5 oraz na rysunku 4 zmiany mają w przypadku Polski naturę demograficzną. Maksimum w latach 2009-2010 jest związane $\mathrm{z}$ wyżem demograficznym lat 80 . ubiegłego wieku. $\mathrm{O}$ ile wysoki poziom dzietności w Irlandii niekoniecznie świadczy o wysokim poziomie życia rodzin, choć jest z takim poglądem $\mathrm{w}$ pełni zgodny, o tyle niski poziom $\mathrm{w}$ Polsce wygląda na związany z trudną sytuacja rodziny w Polsce. Wymienienie wszystkich powszechnie znanych mających znaczenie czynników przekracza jednak ramy niniejszego artykułu.

\subsection{Liczba zawieranych małżeństw i przeprowadzanych rozwodów}

Dane podane w tabeli 6 i przedstawione na rysunku 5 dotycza liczby zawieranych małżeństw oraz przeprowadzanych rozwodów na 10 tysięcy mieszkańców osobno dla Polski i Irlandii. Pierwszy z tych mierników ma głównie naturę demograficzną. Wpływ na niego ma również społeczna preferencja do formalizowania związków. Liczba zawieranych małżeństw jest na podobnym poziomie w obu krajach, choć wyraźnie widoczne jest maksimum obserwowane dla Polski w roku 2008; tak jak poprzednio, związane z wyżem demograficznym. Podobna częstość zawierania małżeństw mogłaby stanowić podstawę do uznania drugiego z mierników, czyli częstości rozwodów, jako dobrego narzędzia statystycznego porównania jakości

Tabela 5. Liczba dzieci przypadających na jedną kobietę w UE28, Irlandii i Polsce w 2004-2013

\begin{tabular}{|l|c|c|c|c|c|c|c|c|c|c|}
\hline \multirow{2}{*}{ Kraj } & \multicolumn{10}{|c|}{ Rok } \\
\cline { 2 - 11 } & $\mathbf{2 0 0 4}$ & $\mathbf{2 0 0 5}$ & $\mathbf{2 0 0 6}$ & $\mathbf{2 0 0 7}$ & $\mathbf{2 0 0 8}$ & $\mathbf{2 0 0 9}$ & $\mathbf{2 0 1 0}$ & $\mathbf{2 0 1 1}$ & $\mathbf{2 0 1 2}$ & $\mathbf{2 0 1 3}$ \\
\hline EU28 & 1,50 & 1,51 & 1,54 & 1,56 & 1,61 & 1,61 & 1,62 & 1,58 & 1,58 & 1,55 \\
\hline Irlandia & 1,93 & 1,86 & 1,91 & 2,01 & 2,06 & 2,06 & 2,05 & 2,03 & 2,01 & 1,96 \\
\hline Polska & 1,23 & 1,24 & 1,27 & 1,31 & 1,39 & 1,41 & 1,41 & 1,33 & 1,33 & 1,29 \\
\hline
\end{tabular}

Źródło: opracowanie własne na podstawie danych ze strony http://ec.europa.eu/eurostat/tgm/table. do tab $=$ table \&init $=1 \&$ plugin $=1 \&$ pcode $=$ tsdde220\&language $=$ en [tsdde220] $(02.02 .2016)$.

Rysunek 4. Liczba dzieci przypadających na jedną kobietę w UE 28, Irlandii i Polsce w 2004-2013

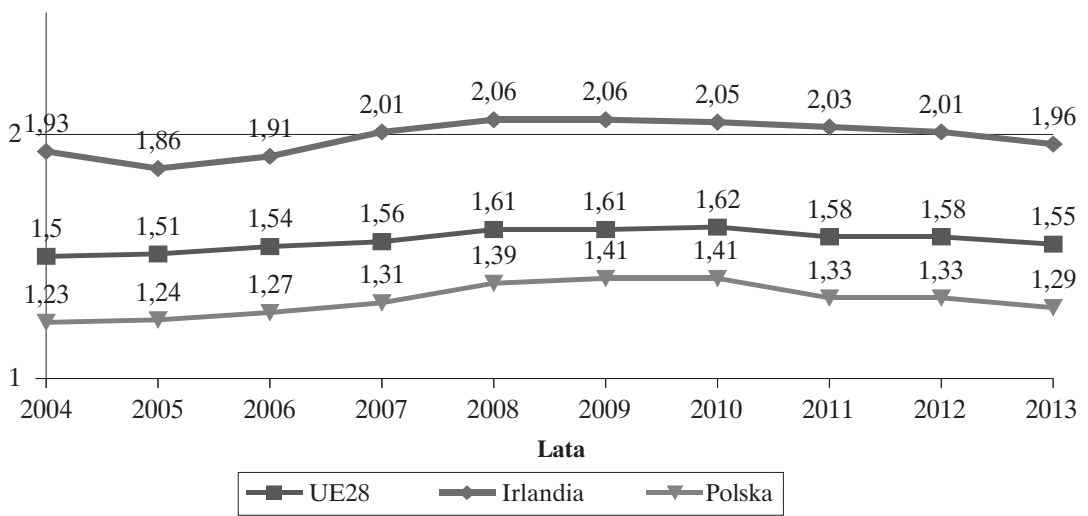

Źródło: opracowanie własne na podstawie danych ze strony http://ec.europa.eu/eurostat/tgm/table.do? tab $=$ table\&init $=1$ \&plugin $=1 \&$ pcode $=$ tsdde220\&language $=$ en [tsdde220] $(02.02 .2016)$. 
Tabela 6. Liczba zawieranych małżeństw oraz przeprowadzanych rozwodów na 10000 mieszkańców w latach 2004-2013 w Polsce i Irlandii

\begin{tabular}{|c|c|c|c|c|c|c|c|c|c|c|c|}
\hline \multirow{2}{*}{ 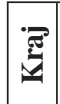 } & \multirow{2}{*}{ Miernik } & \multicolumn{10}{|c|}{ Rok } \\
\hline & & 2004 & 2005 & 2006 & 2007 & 2008 & 2009 & 2010 & 2011 & 2012 & 2013 \\
\hline \multirow{3}{*}{$\begin{array}{l}\underset{\Xi}{\overparen{\Xi}} \\
\stackrel{\Xi}{\Xi} \\
\stackrel{\Xi}{\Xi}\end{array}$} & $\begin{array}{l}\text { Liczba } \\
\text { małżeństw }\end{array}$ & 20979 & 21355 & 22089 & 22756 & 22187 & 21627 & 20594 & 19855 & 20713 & bd \\
\hline & $\begin{array}{l}\text { Liczba } \\
\text { rozwodów }\end{array}$ & 3100 & 3400 & 3684 & 3684 & 3630 & 3341 & 3113 & 2819 & 2892 & bd \\
\hline & $\begin{array}{l}\text { Liczba } \\
\text { rozwodów } \\
\text { w stosunku } \\
\text { do liczby } \\
\text { małżeństw } \\
(\text { w \%) }\end{array}$ & 14,78 & 15,92 & 16,68 & 16,19 & 16,36 & 15,45 & 15,12 & 14,2 & 13,96 & - \\
\hline \multirow{3}{*}{$\begin{array}{l}\frac{\pi}{\sqrt[y]{2}} \\
\frac{0}{2} \\
2\end{array}$} & $\begin{array}{l}\text { Liczba } \\
\text { małżeństw }\end{array}$ & 191824 & 206916 & 226181 & 248702 & 257744 & 250794 & 228377 & 206471 & 203850 & 180396 \\
\hline & $\begin{array}{l}\text { Liczba } \\
\text { rozwodów }\end{array}$ & 56332 & 67578 & 71912 & 66586 & 65475 & 65345 & 61300 & 64594 & 64432 & 66132 \\
\hline & $\begin{array}{l}\text { Liczba } \\
\text { rozwodów } \\
\text { w stosunku } \\
\text { do liczby } \\
\text { małżeństw } \\
(\text { w \%) }\end{array}$ & 29,37 & 32,66 & 31,79 & 26,77 & 25,4 & 26,06 & 26,84 & 31,28 & 31,61 & 36,66 \\
\hline
\end{tabular}

Źródło: opracowanie własne na podstawie: http://appsso.eurostat.ec.europa.eu/nui/show.do?datase$t=d e m o \_n i n d \& l a n g=e n$ (małżeństwa) oraz http://appsso.eurostat.ec.europa.eu/nui/show.do?datase$t=$ demo_ndivind\&lang $=$ en (rozwody) (16.07.2015).

Rysunek 5. Liczba zawieranych małżeństw oraz przeprowadzanych rozwodów na 10000 mieszkańców w latach 2004-2013 w Polsce i Irlandii

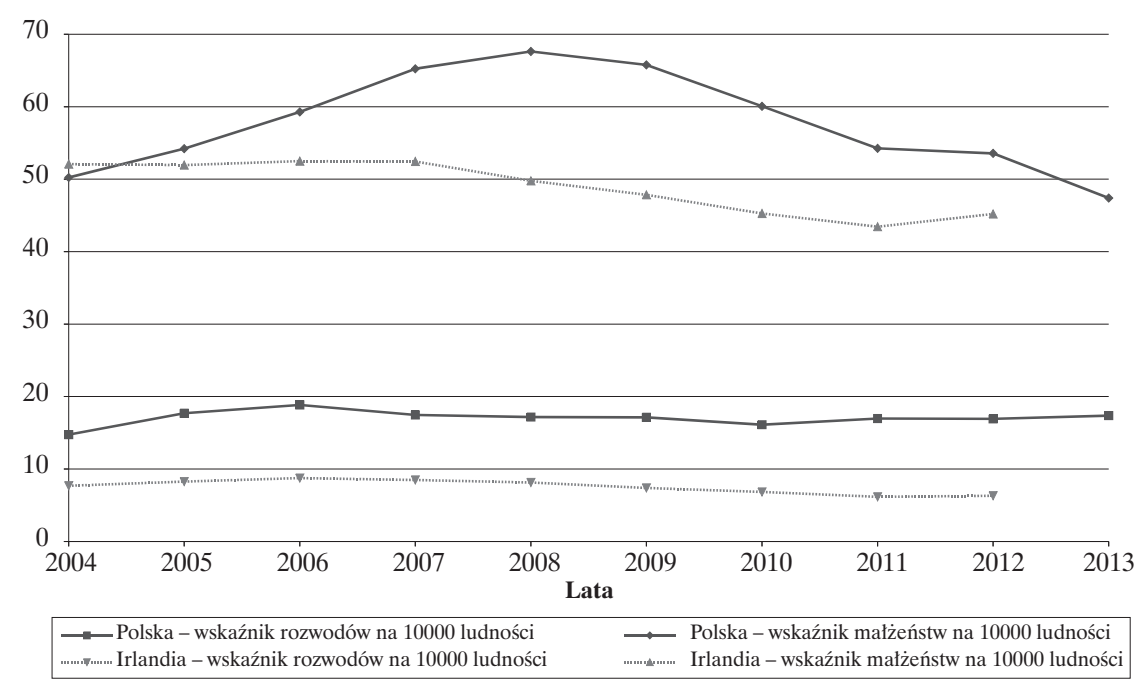

Źródło: opracowanie własne na podstawie: http://appsso.eurostat.ec.europa.eu/nui/show.do?datase$t=$ demo nind\&lang =en (małżeństwa) oraz http://appsso.eurostat.ec.europa.eu/nui/show.do?datase$t=$ demo_ndivind\&lang=en (rozwody) (16.07.2015). 
życia rodzin w obu krajach. Liczba rozwodów na 10 tysięcy mieszkańców jest około dwa razy wyższa w Polsce niż w Irlandii. Mniej więcej co trzecie polskie małżeństwo się rozpada, podczas gdy w Irlandii tylko około co piąte. Prosty wniosek o dużo niższej jakości życia rodzin w Polsce jest jednak pochopny. Przeprowadzenie procesu rozwodowego jest znacznie trudniejsze w Irlandii niż w Polsce. Na przykład należy wykazać przynajmniej czteroletni rozkład pożycia małżeńskiego, a rozwody w Irlandii zostały dopuszczone zaledwie 20 lat temu, dzięki minimalnej przewadze referendalnej zwolenników takiego rozwiązania.

\section{Podsumowanie}

W artykule podjęto próbę analizy porównawczej jakości życia rodzin w dwóch wybranych krajach - Irlandii oraz Polsce w latach 2004-2013. Po pierwsze Irlandia przeznacza obecnie na pomoc socjalną dla rodzin 3,9\% PKB, a Polska jedynie 1,3\%. Po drugie Irlandia posiada szerszy katalog powszechnych materialnych świadczeń rodzinnych. Polska w tym zakresie oferuje jedno świadczenie powszechne. Większość świadczeń w Polsce jest przeznaczona dla rodzin ubogich. Po trzecie wysokość pobieranych w Irlandii świadczeń jest zdecydowanie wyższa niż świadczeń w Polsce. Dodatkowo, okres pobieranych świadczeń jest dłuższy w Irlandii niż w Polsce. W związku z tym można jednoznacznie stwierdzić, że świadczenia dla rodzin w Irlandii są lepiej i przystępniej skonstruowane. Można przypuszczać, że tak prowadzona polityka ma pewien wpływ na podejmowanie decyzji przez młodych ludzi - zarówno o założeniu rodziny, jak i o posiadaniu dzieci. W artykule pokazano, że w analizowanych latach populacja Irlandii wzrosła o około $14 \%$, Polski zmniejszyła się o 0,34\%. Skumulowane saldo migracji dla Polski w badanym okresie wyniosło -474,5 tysięcy osób, dla Irlandii 165 tysięcy osób.

Należy jednak zwrócić uwagę na fakt, że poziom emigracji z Irlandii jest wyraźnie wyższy niż z Polski. Dodatnie saldo migracji w Irlandii wynika $z$ jeszcze wyższego poziomu imigracji. Oznacza to, że Irlandia choć postrzegana przez imigrantów jako dobre miejsce do życia, to dla porównywalnej części jej mieszkańców jawi się jako niewystarczająco dobra.
Autorki podjęły niezwykle ważne zagadnienia powszechnych świadczeń dla rodzin w kontekście jakości życia rodzin, problematykę wielowymiarową i złożoną. Mają nadzieje, że niniejszy artykuł będzie stanowił zachętą do dalszych badań i analiz na temat jakości życia rodzin.

\section{Przypisy}

1 Ustawa z dnia 25 lutego 1964 r. Kodeks rodzinny i opiekuńczy (Dz. U. z 1964 r., Nr 9, poz. 59 ze zm.), art. 27

2 http://sjp.pl/rodzina (22.03.2015).

3 Konstytucja Rzeczypospolitej Polskiej z dnia 2 kwietnia 1997 (Dz. U. z 1997 r. Nr 78, poz. 483, z 2001 r. Nr 28, poz. 319, z 2006 r. Nr 200, poz. 1471), Rozdział I - Rzeczpospolita, art. 18.

4 Opracowano na podstawie informacji http:// www.mpips.gov.pl; http://www.citizensinformation.ie/en/.

5 Urząd ds. Szkoleń i Zatrudnienia w Irlandii.

6 https://www.welfare.ie/en/Pages/273_Child-Benefit.aspx (dostęp 19.04.2015).

7 https://www.welfare.ie/en http://www.citizensinformation.ie/en/

8 http://www.citizensinformation.ie/en/social_welf are/social_welfare_payments/social_welfare pay ments_to_families_and_children/maternity_ benefit.html (dostęp 19.04.2015).

9 www.dziennikustaw.gov.pl/du/2016/214/D201 6000021401.pdf

10 Wspólna umowna jednostka walutowa stosowana w Unii Europejskiej do przeliczeń zagregowanych danych ekonomicznych dla potrzeb porównań przestrzennych, w taki sposób, aby wyeliminować różnice $\mathrm{w}$ poziomach cen między państwami członkowskimi (GUS 2016, http://stat.gov.pl/metainformacje/slownik-pojec/pojecia-stosowane-wstatystyce-publicznej/3782,pojecie.html).

\section{Bibliografia}

Adamowicz, E. i in. (2008). Ekonomia bez tajemnic, Cz. 2, Wyd. 5. Warszawa: Wydawnictwa Szkolne i Pedagogiczne.

Balcerzak-Paradowska, B. (2011). ABC polityki rodzinnej. Kraków: Znak.

Bradford, R., Rutherford, D.L. i John, A. (2002). Quality of life in young people: ratings and factor structure of the Quality of Life Profile - Adolescent Version. Journal of Adolescence, 25(3), 261-274, http://dx.doi.org/10.1006/jado.2002.0469

Constanza, R. i in. (2007) Quality of life: An approach integrating opportunities, human needs, and subjective well-being, Ecological Economics, 61, 267276, http://dx.doi.org/10.1016/j.ecolecon.2006.02.023 
Diener, E. i Suh, E. (1997). Measuring quality of life: economic, social, and subjective indicators. Social Indicators Research, 40(1), 189-216, http:// dx.doi.org/10.1023/a:1006859511756

Gotay, C.C. i Muraoka, Y.M. (1998). Quality of Life in Long-Term Survivors of Adult-Onset Cancers', JNCI, 90(9), 656-667, http://dx.doi. org/10.1093/jnci/90.9.656

Hagerty, M.R., Cummins, R.A., Ferriss, A.L., Land, K., Michalos, A.C., Peterson, M., Sharpe, A. Sirgy, J. i Vogel, J. (2001) Quality of Life Indexes for National Policy: Review and Agenda for Research. Bulletin de Méthodologie Sociologique, 71(1), 58-78, http://dx.doi.org/10.1177/075910630107100104

Kurzynowski, A. (1991). Problemy rodziny w polityce spotecznej. Warszawa: Ośrodek Badań Społecznych

Mazur, J. (2013). Pro familia et societate: wybrane zagadnienia polityki społecznej. Kraków: Wyd. Naukowe UPJPII.

Nussbaum, M. i Sen, A. (red.) (1993). The Quality of Life. Oxford University Press, http://dx.doi. org/10.1093/0198287976.001.0001

OFS (2014). Audit urbain La qualit é de vie dans les villes. Neuchâtel: Office fédéral de la statistique (OFS).
Orczyk, J. (2012). Polityka spoteczna: uwarunkowania $i$ cele. Poznań: Wydawnictwo Uniwersytetu Ekonomicznego w Poznaniu.

Ordo Iuris (2015). Jakiej polityki rodzinnej potrzebuje Polska? Warszawa: Ordo Iuris.

Reynard, R. (2016). La qualité de vie dans les territoires français. Revue de l'OFCE, 1/2016 (145), $33-48$.

Rysz-Kowalczyk, B. (red.) (2002). Leksykon polityki społecznej. Warszawa: Instytut Polityki Społecznej UW.

Stiglitz, J.E., Sen, A. i Fitoussi, J.-P. (2009). Report by the Commission on the Measurement of Economic Performance and Social Progress, www.stiglitz-senfitoussi.fr

Święch, K. (2013). Pozycja rodziny w polskim prawie podatkowym. Warszawa: Wolters Kluwer Polska.

Zalewska, M. (2013). Paradygmat zrównoważonego rozwoju w strategiach nowych państw członkowskich UE. Handel Wewnętrzny, 6(67).

Zalewska, M. (2015). Ograniczenia wskaźników zdrowia publicznego monitorowanych w kontekście zrównoważonego rozwoju. Problemy Zarzadzania, 13 . 